Original Paper http://ajol.info/index.php/ijbcs http://indexmedicus.afro.who.int

\title{
Agro-morphological diversity of plantain accessions from different part of the world
}

\author{
Amien Isaac AMOUTCHI ${ }^{1}$, Oulo N'NAN-ALLA ${ }^{1 *}$ and \\ Deless Edmond Fulgence THIEMELE ${ }^{2}$
}

\author{
${ }^{1}$ Laboratoire de Génétique, UFR Biosciences, Université Félix Houphouët-Boigny (UFHB), Abidjan, \\ Côte d'Ivoire, 22 BP Abidjan 22, Côte d'Tvoire. \\ ${ }^{2}$ Laboratoire de Biochimie-Génétique, UFR Sciences Biologiques, Université Péléforo Gon Coulibaly (UPGC) \\ Korhogo, Côte d'Ivoire ; BP 1328, Côte d'Ivoire. \\ ${ }^{*}$ Corresponding author ; E-mail : nanoulo@yahoo.fr; Tél : (+ 225) 07164327.
}

\begin{abstract}
The objective of this study was to characterize the agro-morphological diversity of plantain accessions. 18 quantitative variables and 20 qualitative variables were measured. The results of the analysis of the qualitative variables revealed important traits such as black Sigatoka resistance of FHIA 21, Pita 3, M53, Calculta 4 and Banskii accessions and the firm fruit texture of Galeo, Kokor, French sombre and Corne 1 accessions. A Principal Component Analysis (PCA) performed with the quantitative variables separated the 9 accessions into 4 groups with particular and important characteristics which can be exploited differently in genetic improvement programme according to the breeding objective. From these results, it appears clearly that the objective is achieved.
\end{abstract}

(C) 2020 International Formulae Group. All rights reserved.

Keywords: Sigatoka, qualitative variables, quantitative variables, genetic improvement.

\section{INTRODUCTION}

Banana and plantain trees (Musa spp., $\mathrm{AAA}, \mathrm{AAB}$ and $\mathrm{ABB}$ ) produce one of the essential starchy foods for developing countries (Shirani et al., 2009). They are native to South-East Asia (Swennen and Vuylsteke, 2001). Over the years, they have occupied strategic places in agricultural production across Africa continent (Chah et al., 2012). Banana and plantain rank as the fourth most important global food product after rice, wheat and maize in terms of gross value of production (Chah et al., 2012). Worldwide, plantain and banana production was estimated to around 40 millions of tones in 2018 (FAO, 2019). About $90 \%$ of banana and plantain production is consumed locally in the producing countries, while the remaining $10 \%$ is exported (Nwauzoma et al., 2011). In Côte d'Ivoire, banana is the third staple food after yam and cassava (FAO, 2016) and 80 to $120 \mathrm{~kg}$ are consumed per inhabitant and per year (cite an authority). It accounts for 8 to $10 \%$ of agricultural GDP (Ocab, 2012).

Despite the economic importance of banana and plantain, their production across the globe has decreased over the years due to declining soil fertility, reduced yields, pest attacks (weevils, nematodes), cryptogamic diseases such as black Sigatoka caused by Mycosphaerella fijiensis (Nwauzoma et al., 2011) and viral diseases (Banana streak virus, Banana Bunchy Top Virus, etc.). Chemical products are reported to be efficient in the 
control of these diseases, but the cost of these chemicals (fungicides and pesticides) are often beyond the purchasing power of poor farmers (Oselebe et al., 2006). In addition, environmentalists and consumers concerned about the preservation of the environment protest against the massive use of chemicals products (Gueye et al., 2020). Therefore, the selection of high-yielding varieties that are resistant to bio-aggressors through genetic improvement appear to be perfect solution (Coretta et al., 2020).

In the 1990s, research activities have been mainly focused on increasing yields and resistant varieties to black Sigatoka. In 1997 and 1998, this led to the selection of several resistant varieties including Pita 3 and FHIA 21. These varieties have become popular in Côte d'Ivoire through the West Africa Agricultural Productivity Program (WAAPP) initiated in 2011 and they were successfully used by producers. However, the susceptibility of these varieties to the Banana streak virus (BSV) and the quality of their fruits which does not meet the consumers' needs have been a barrier to the widespread distribution of these high-yielding varieties. In order to find a solution to these constraints through selection of new varieties, some accessions of banana were chosen across the world our team for different intraspecific hybridizations. However, these accessions are still poorly known. Hence, the present study was design to characterize agro-morphological diversity of these plantain accessions.

\section{MATERIALS AND METHODS Plant material}

The plant material was composed of banana plants obtained from the suckers of nine (9) banana accessions (Table 1) including local landraces, wild relatives, interspecific F1 hybrid progenies and cultivars originating from Côte d'Ivoire, Papua New Guinea (PNG), Cameroon, India and Honduras. A total of 5 plants were used per accession.

\section{Site of the Study}

The experiments were carried out in southern Côte d'Ivoire, in an experimental site of the National Center for Agronomic Research (CNRA) located in Azaguié. Azaguié is a city located in the Agneby-Tiassa administrative region and in the department of Agboville, 50 $\mathrm{km}$ from Abidjan, at latitude $5^{\circ} 38^{\prime} \mathrm{N}$ and longitude $4^{\circ} 05^{\prime} \mathrm{W}$. The vegetation consists of dense forest and the soil texture is sandy-clay.

\section{Experimental design}

Suckers of the different accessions were planted onto the experimental plot, in July 2016, during the long rainy season, in a completely randomized Fisher block. The plants were spaced by 2 and $3 \mathrm{~m}$, respectively between and within rows in order to obtain a density of 1667 per hectare.

\section{Planting of the suckers}

Planting of the suckers was carried out in different steps. Before the rainy season, the plots were first weeded and then the soil was deeply ploughed. Then staking was performed according to the planting density and a hole of $64,000 \mathrm{~cm}^{3}(40 \times 40 \times 40 \mathrm{~cm})$ was dug at the location of each stake. Before planting, the suckers, they were pared by removing the necrotic roots in order to eliminate weevils and nematodes. Then, the suckers were planted in the holes containing a mixture of topsoil and a fertilizer consisting of $150 \mathrm{~g}$ of phosphate and $250 \mathrm{~g}$ of dolomite. Finally, the holes were filled with soil to a level of $10 \mathrm{~cm}$ above ground level.

\section{Monitoring of experimental plots}

Experimental plots were weeded with a hoe and a machete. Bamboo stems were used as stakes to support the banana trees and their fruits in order to avoid any lodging that could be caused by the weight of bananas bunches, strong winds or weak root systems. The necrosed leaves due to black Sigatoka were removed using knives.

\section{Data collection}

The plants were characterized at flowering stage, 7 to 9 months after planting, using 40 agro-morphological traits selected from the descriptors list for plantains and banana (IBPGR-INIBAP/CIRAD, 1996), including 18 quantitative variables (Table 2) and 20 qualitative variables (Table 3). 


\section{Data analysis}

Frequencies of the different modalities of each qualitative variable were calculated. Descriptive statistics (mean value, minimum, maximum and standard deviation) of each quantitative variable were calculated. Agromorphological diversity of the accessions of plantains was structured using a principal component analysis (PCA). Relevant descriptors and factorial components of the PCA were identified based on coefficients of correlation and the quality of representation, on one hand, and on Kaiser's criterion, on the other hand. All the statistical analyses were performed with the software XLSTAT 2016.

Table 1: List of the studied plantain accessions.

\begin{tabular}{lllll}
\hline $\mathbf{N}^{\circ}$ & Accession & Group & Type & Origin \\
\hline 1 & Banksii & AA & Wild relative & Papua New Guinea \\
2 & M53 & AA & Wild relative & Cameroon \\
3 & Kokor & AS & cultivars & Papua New Guinea \\
4 & PITA 3 & AAAB & Improved & Cameroon \\
5 & FHIA 21 & AAAB & Improved & Honduras \\
6 & French sombre & AAB & local landrace & Côte d'Ivoire \\
7 & CORNE 1 & AAB & local landrace & Côte d'Ivoire \\
8 & CALCULTA 4 & AA & Wild relative & India \\
9 & GALEO & AA & cultivars & Papua New Guinea \\
\hline
\end{tabular}

Table 2: Quantitative agro-morphological traits scored on the studied plantain accessions.

\begin{tabular}{llll}
\hline $\mathbf{N}^{\circ}$ & Agro-morphological trait & Unity (IS) & Abbreviation \\
\hline 1 & Pseudo-trunk height & $\mathrm{m}$ & PTH \\
2 & Bunch weight & $\mathrm{kg}$ & BUW \\
3 & Number of hands per bunch & - & NHB \\
4 & Number of fingers per bunch & - & NFB \\
5 & Fruit length & $\mathrm{cm}$ & FRL \\
6 & Fruit pedicel length & $\mathrm{cm}$ & FPL \\
7 & Fruit pedicel diameter & $\mathrm{mm}$ & FPD \\
8 & Fruit skin thickness & $\mathrm{mm}$ & FST \\
9 & Number of suckers per plant & - & NSP \\
10 & Number of living leaves at flowering stage & - & NLF \\
11 & Number of living leaves at harvest stage & - & NLH \\
12 & Leaf blade width & $\mathrm{cm}$ & LBW \\
13 & Leaf blade length & $\mathrm{cm}$ & LBL \\
14 & Leaf margin width & $\mathrm{cm}$ & LMW \\
15 & Petiole length & $\mathrm{cm}$ & PEL \\
16 & Peduncle length & $\mathrm{cm}$ & PDL \\
17 & Peduncle diameter & $\mathrm{cm}$ & PDD \\
\hline 18 & Male bud length & $\mathrm{cm}$ & MBL \\
\hline
\end{tabular}

IS : International System

Legend PTH = Pseudo-trunk height, $\mathrm{BUW}=$ Bunch weight, $\mathrm{NHB}=$ Number of hands per bunch, NFB = Number of fruits per bunch, FRL $=$ Fruit length, FPL $=$ Fruit pedicel length, FPD $=$ Fruit pedicel diameter, FST $=$ Fruit skin thickness, NSP $=$ Number of suckers per plant, NLF $=$ Number of living leaves at flowering stage, NLH $=$ Number of living leaves at harvest stage, $\mathrm{LBW}=$ Leaf blade width, $\mathrm{LBL}=$ Leaf blade length, $\mathrm{LMW}=$ Leaf margin width, $\mathrm{PEL}=$ Petiole length, $\mathrm{PDL}=$ Peduncle length, $\mathrm{PDD}=$ Peduncle diameter, $\mathrm{MBL}=$ Male bud length. 
Table 3: Qualitative agro-morphological traits evaluated in the studied plantain accessions.

\begin{tabular}{|c|c|c|c|}
\hline \multirow[b]{2}{*}{$\mathrm{N}^{\circ}$} & \multirow{2}{*}{ Variable } & \multicolumn{2}{|c|}{ Modalities } \\
\hline & & Code & modality \\
\hline \multirow[b]{2}{*}{1} & \multirow{2}{*}{ Foliar growth habit } & 1 & Erected \\
\hline & & 2 & Normal \\
\hline \multirow[b]{2}{*}{2} & \multirow{2}{*}{ Dwarfism } & 1 & Normal \\
\hline & & 2 & Dwarf \\
\hline \multirow{5}{*}{3} & \multirow{5}{*}{ Color of the pseudo-trunk } & 1 & green yellow green \\
\hline & & 2 & Medium green \\
\hline & & 3 & Green \\
\hline & & 4 & Dark Green \\
\hline & & 7 & purplish red \\
\hline \multirow{3}{*}{4} & \multirow{3}{*}{ Discharges with tubular sheets } & 1 & $\begin{array}{l}\text { Discharges with } \\
\text { tubular sheets }\end{array}$ \\
\hline & & 2 & $\begin{array}{l}\text { No discharges with } \\
\text { tubular sheets }\end{array}$ \\
\hline & & 2 & $\begin{array}{l}\text { Adjacent to the mother } \\
\text { foot }\end{array}$ \\
\hline \multirow{5}{*}{5} & \multirow{5}{*}{ Position of the speed } & 1 & During vertically \\
\hline & & 2 & Slightly oblique \\
\hline & & 3 & Oblique $45^{\circ}$ angle \\
\hline & & 4 & Horizontal \\
\hline & & 5 & Erected \\
\hline \multirow[t]{2}{*}{6} & \multirow{2}{*}{ Form of the plan } & 1 & Cylindrical \\
\hline & & 2 & truncated cone \\
\hline \multirow{4}{*}{7} & \multirow{4}{*}{ Compactness of the speed } & 1 & Cowardly \\
\hline & & 2 & Compact design \\
\hline & & 3 & Asymmetrical \\
\hline & & 4 & Spiral \\
\hline \multirow{3}{*}{8} & \multirow{3}{*}{ presence of pollens } & 1 & Strong \\
\hline & & 2 & Medium \\
\hline & & 3 & Low \\
\hline \multirow{5}{*}{9} & \multirow{5}{*}{ Fruit position } & 1 & $\begin{array}{l}\text { curved towards the } \\
\text { shaft }\end{array}$ \\
\hline & & 2 & Parallel to the shaft \\
\hline & & 3 & Straightened \\
\hline & & 4 & $\begin{array}{l}\text { perpendicular to the } \\
\text { shaft }\end{array}$ \\
\hline & & 5 & During \\
\hline \multirow{8}{*}{10} & \multirow{4}{*}{ Fruit shape } & 1 & Right \\
\hline & & 2 & right in the distal part \\
\hline & & 3 & Curve \\
\hline & & 4 & S-bent \\
\hline & \multirow{4}{*}{ Colour of the fruit skin before maturity } & 1 & Yellow \\
\hline & & 2 & light green \\
\hline & & 3 & Green Green \\
\hline & & 4 & Green and pink \\
\hline
\end{tabular}




$\begin{array}{cl}5 & \text { Silvered } \\ 6 & \text { Dark Green } \\ 7 & \text { Brown /rust brown } \\ 8 & \text { Pink, red or purple } \\ 9 & \text { Black } \\ 10 & \text { Mixed green and } \\ & \text { yellow/white }\end{array}$

Table 3 (c

rariables evaluated in the studied plantain accessions

\begin{tabular}{|c|c|c|c|}
\hline \multirow[t]{2}{*}{$\mathrm{N}^{\circ}$} & \multirow{2}{*}{ Variable } & \multicolumn{2}{|c|}{ Modalities } \\
\hline & & Code & modality \\
\hline \multirow[t]{2}{*}{12} & \multirow{2}{*}{ Presence of skin cracks } & 1 & no cracking \\
\hline & & 2 & Cracking \\
\hline \multirow[t]{2}{*}{13} & \multirow{2}{*}{ Pulp in the fruit } & 1 & Without pulp \\
\hline & & 2 & With pulp \\
\hline \multirow[t]{6}{*}{14} & \multirow{6}{*}{ Color of the pulp before maturity } & 1 & White \\
\hline & & 2 & Cream \\
\hline & & 3 & Ivory \\
\hline & & 4 & Yellow \\
\hline & & 5 & Orange \\
\hline & & 6 & Beige-pink \\
\hline \multirow[t]{6}{*}{15} & \multirow{6}{*}{ Colour of the pulp at maturity } & 1 & White \\
\hline & & 2 & Cream \\
\hline & & 3 & Ivory \\
\hline & & 4 & Yellow \\
\hline & & 5 & Orange \\
\hline & & 6 & Beige-pink \\
\hline \multirow[t]{2}{*}{16} & \multirow{2}{*}{ Falling fruit } & 1 & Persistent \\
\hline & & 2 & Falling out of hands \\
\hline \multirow[t]{2}{*}{17} & \multirow{2}{*}{ Texture of the pulp } & 1 & Farmhouse \\
\hline & & 2 & Soft \\
\hline \multirow[t]{5}{*}{18} & & 1 & Apre (cooking banana) \\
\hline & & 2 & Bland \\
\hline & Dominant flavor & 3 & Soft \\
\hline & & 4 & Sweetened \\
\hline & & 5 & Acidic \\
\hline \multirow[t]{3}{*}{19} & & 1 & $<5$ \\
\hline & Presence of seeds with pollen source & 2 & $5-20$ \\
\hline & & 3 & $>20$ \\
\hline \multirow[t]{2}{*}{20} & \multirow{2}{*}{ presence of Sigatoka } & 1 & Absent \\
\hline & & 2 & Present \\
\hline
\end{tabular}




\section{RESULTS}

\section{Characterization of the Agro-morphological diversity through the Qualitative variables}

Among the 20 qualitative variables assessed (Table 4), four showed no difference in modalities between the accessions. A pseudo-trunk colour was yellow green (11.11\%) for the Pita3 accession, dark green (11.11\%) for the French sombre accession, green $(66.67 \%)$ for KOKOR, FHIA 21, Corne 1, M53 and Banskii accessions, and purplish red $(11.11 \%$.) for Galeo accessions. The fruits coloration of the different accessions varied from one stage of maturity to another. Before maturity, only M53 fruits were green (11.11\%). Pita3, Calculta 4, Corne 1, Banskii, Kokor and FHIA 21 and Galeo fruits colour were green (77.78\%), and French Dark fruits colour was silver $(11.11 \%)$. At maturity, the majority of fruits from the different accessions were yellow $(88.89 \%)$, except Corne 1 which had bright yellow fruit colour $(11.11 \%)$. For the texture of the fruit pulp, among the nine accessions assessed, four (Galeo, Kokor, French Dark and Corne 1) had a firm texture (44.44\%), and the five other accessions (Caculta 4, M53, FHIA 21, Pita 3 and Banskii) had $55.56 \%$ soft-flesh fruit texture. FHIA 21 pollen quantity was highest, followed by Pita3, Calculta4, M53 and Banskii with moderate pollen quantity, and finally French Dark, Galeo, Kokor and Corne 1 with lowest pollen quantity. Black sigatoka disease symptoms were not observed from FHIA 21, Pita 3, M53, Calculta 4 and Banskii accessions. However, and the four others accessions (Kokor, Galeo, French dark and Corne 1) developed black sigatoka symptoms.

\section{Agro-morphological diversity characterization through the Quantitative variables \\ Quantitative Variables descriptive statistics Descriptive statistics (means,} minimum, maximum, standard deviations and coefficients of variation) of all quantitative traits are presented in Table 5. Standard deviations of the number of fruits per bunch (NFB), the fruit length (FRL), the leaf blade width (LB), the leaf blade length (LBL), the petiole length (PEL), the peduncle length (PDL) and the male bud length (MBL), were high. That mean, there was high dispersion around means value of these variable. The others variables presented low standard deviations values, meaning accessions values for these variables tend to be close to their means values.

However, the mean value of the pseudotrunk height was $2.66 \mathrm{~m}$, with a maximum value of $3.56 \mathrm{~m}$ recorded for Pita3 and a minimum value of $2.40 \mathrm{~m}$ recorded for the accession Caculta 4. The number of suckers ranged from 3 to 9, with a mean value of 5.04. French sombre had the maximum value ( 9 suckers), while Banksii recorded the minimum value (3 suckers) of suckers. The number of living leaves during the flowering stage and harvesting stage ranged respectively from around 3 to 9 and from approximatively 2 to 6 , with respective averages of 5.78 and 3.44. The accession FHIA 21 accession recorded the maximum living leaves at flowering and at harvesting, while the accession Galeo presented minimum number of living leaves at flowering stage and accessions Corne 1, Calculta 4, Galeo and M53 obtained the minimum of living leaves at harvesting stage.

The bunch weight ranged from $7.2 \mathrm{~kg}$ (for Pita3 accession) to $2.36 \mathrm{~kg}$ (for Banksii accession), with an average of 5.10. The number of hands per bunch fluctuated from around 5 recorded for Bansksii and Galeo accessions to around 8 recorded for M53accession, with an average of 6.11. The number of fruits oscillated between 29 for Corne 1 accession and 118 for M53 accession, with an average of 59.82 .

\section{Structuring Agro-morphological diversity of accessions through Principal Component Analysis (PCA)}

Tables 6, 7 and 8 presented respectively the amount of variability explained by each of the first five factorial components highlighted by the principal component analysis, the square cosines of the quantitative variables and the correlations between the variables and the components (axes). These components have eigenvalues greater than 1 and explained 
around $92.43 \%$ of the diversity. However, the first two components which cumulated about $76.18 \%$ of the total variance are most relevant. Indeed, these components have the highest eigenvalues and are strongly correlated with different quantitative variables (Table 6 and 7). They were therefore selected to describe the structuring of the quantitative agromorphologic diversity of plantain accessions.

The first component (F1) which explains around $46.86 \%$ of the observed variability is highly positively correlated with the following variables: Pseudo-trunk height (PTH), bunch weight(BUW), fruit pedicel length (FPL), fruit skin thickness (FST), number of living leaves at flowering stage (NLF), number of living leaves during the harvesting stage (NLH), Leaf blade width (LBW), Leaf blade length (LBL ), leaf margin width (LMW), peduncle length (PDL ), peduncle diameter (PDD) and the male bud length (MBL). This means that these variables were positively correlated with each other.

The second component (F2) explains about $19.05 \%$ of the total variance and is positively correlated with the number of suckers per plant (NSP) and the petiole length (PEL). This component is also highly negatively correlated with the number of fruits per bunch (NFB) and the fruit length (FRL).
The projection of the accessions and variables on these two first components allowed the grouping of the accessions into four groups (Figure 1).

- The component 1, opposite two types of individuals: on the left the individuals of the group I (Galeo and Kokor) and the group III (Banksii, M53 and calculta 4), which are short sizes, with small leaves, reduced peduncle lengths, small size of male buds, small bunches and with few living leaves at flowering and harvesting stages. And at the right the individuals of the group II (FHIA 21 and Pita 3) and group IV (Corne 1 and French dark), with big sizes, big leaves, big bunch, high numbers of living leaves at flowering and harvesting, thick-skinned fruits, long male buds, and big and long peduncle.

- $\quad$ The second component (F2) opposite the individuals of group II (FHIA 21 and Pita 3) and III (Banksii, M53 and calculta 4) are characterized by high number of small size fruits and small number of suckers to the individuals of group I (Galeo and Kokor). Group IV (Corne 1 and French dark) is characterized by the highest number of suckers and small numbers of big fruits.

Table 4: Frequencies of observed modalities of qualitative traits.

\begin{tabular}{|c|c|c|c|c|}
\hline Variable & Modality & Code & $\begin{array}{l}\text { Numbers of } \\
\text { the modality }\end{array}$ & $\begin{array}{l}\text { Frequency by } \\
\text { modality (\%) }\end{array}$ \\
\hline \multirow{2}{*}{ Foliar growth habit } & Erected & 1 & 5.00 & 55.55 \\
\hline & Normal & 2 & 4.00 & 44.44 \\
\hline Dwarfism & Normal & 1 & 9.00 & 100.00 \\
\hline \multirow{4}{*}{ Color of the pseudo-trunk } & green yellow green & 1 & 1.00 & 11.11 \\
\hline & green & 3 & 6.00 & 66.67 \\
\hline & Dark Green & 4 & 1.00 & 11.11 \\
\hline & purplish red & 7 & 1.00 & 11.11 \\
\hline $\begin{array}{l}\text { Discharges with tubular } \\
\text { sheets }\end{array}$ & $\begin{array}{l}\text { no discharges with } \\
\text { tubular sheets }\end{array}$ & 2 & 9.00 & 100.00 \\
\hline Emission of discharges & $\begin{array}{l}\text { adjacent to the mother } \\
\text { foot }\end{array}$ & 2 & 9.00 & 100.00 \\
\hline \multirow{3}{*}{ Position of the regime } & vertically hanging & 1 & 3.00 & 33.33 \\
\hline & slightly oblique & 2 & 2.00 & 22.22 \\
\hline & $45^{\circ}$ oblique & 3 & 2.00 & 22.22 \\
\hline
\end{tabular}




\begin{tabular}{|c|c|c|c|c|}
\hline & Horizontal & 4 & 2.00 & 22.22 \\
\hline \multirow{2}{*}{ Form of the regime } & Cylindrical & 1 & 7.00 & 77.78 \\
\hline & truncated cone & 2 & 2.00 & 22.22 \\
\hline \multirow{2}{*}{ Compactness of the regime } & Cowardly & 1 & 6.00 & 66.67 \\
\hline & Compact design & 2 & 3.00 & 33.33 \\
\hline \multirow{3}{*}{ fruit position } & curved towards the shaft & 1 & 4.00 & 44.44 \\
\hline & parallel to the shaft & 3 & 2.00 & 22.22 \\
\hline & perpendicular to the shaft & 4 & 3.00 & 33.33 \\
\hline \multirow{2}{*}{ Fruit shape } & right in the distal part & 2 & 3.00 & 33.33 \\
\hline & curve & 3 & 6.00 & 66.67 \\
\hline \multirow{3}{*}{$\begin{array}{l}\text { Colour of the fruit skin before } \\
\text { maturity }\end{array}$} & light green & 2 & 1.00 & 11.11 \\
\hline & green & 3 & 7.00 & 77.78 \\
\hline & silvery & 5 & 1.00 & 11.11 \\
\hline \multirow{2}{*}{ Skin colour at maturity } & yellow & 1 & 8.00 & 88,89 \\
\hline & bright yellow & 2 & 1.00 & 11.11 \\
\hline \multirow{2}{*}{ Presence of skin cracks } & no cracking & 1 & 7.00 & 77.78 \\
\hline & cracks & 2 & 2.00 & 22.22 \\
\hline Pulp in the fruit & with pulp & 2 & 9.00 & 100,00 \\
\hline \multirow{3}{*}{$\begin{array}{l}\text { Color of the pulp before } \\
\text { maturity }\end{array}$} & white & 1 & 6.00 & 66,67 \\
\hline & ivory & 3 & 2.00 & 22,22 \\
\hline & orange & 5 & 1.00 & 11,11 \\
\hline \multirow{2}{*}{ Colour of the pulp at maturity } & cream & 2 & 4.00 & 44,44 \\
\hline & yellow & 4 & 5.00 & 55,56 \\
\hline Falling fruit & Persistent & 1 & 9.00 & 100,00 \\
\hline \multirow{2}{*}{ Texture of the pulp } & firm & 1 & 4.00 & 44.44 \\
\hline & $\operatorname{limp}$ & 2 & 5.00 & 55.56 \\
\hline \multirow{4}{*}{ Dominant flavor } & Apre (cooking banana) & 1 & 4.00 & 44.44 \\
\hline & Bland & 2 & 1.00 & 11.11 \\
\hline & Soft & 3 & 2.00 & 22.22 \\
\hline & Sweetened & 4 & 2.00 & 22.22 \\
\hline \multirow{3}{*}{$\begin{array}{l}\text { Presence of seeds with pollen } \\
\text { source }\end{array}$} & $<5$ & 1 & 1.00 & 11.11 \\
\hline & $5-20$ & 2 & 1.00 & 11.11 \\
\hline & $>20$ & 3 & 7.00 & 77.78 \\
\hline \multirow{3}{*}{ presence of pollens } & Strong & 1 & 1.00 & 11.11 \\
\hline & medium & 2 & 4.00 & 44.44 \\
\hline & Weak & 3 & 4.00 & 44.44 \\
\hline \multirow{2}{*}{ presence of black Sigatoka } & Absent & 1 & 5.00 & 55.56 \\
\hline & present & 2 & 4.00 & 44.44 \\
\hline
\end{tabular}


Table 5: Descriptive statistics of quantitative characters of the studied plantain accessions.

\begin{tabular}{lccccc}
\hline & \multicolumn{5}{c}{ Factorial components } \\
\cline { 2 - 6 } & F1 & F2 & F3 & F4 & F5 \\
\hline Eigenvalue & 8.44 & 3.43 & 1.85 & 1.57 & 1.35 \\
Variance explained (\%) & 46.86 & 19.05 & 10.26 & 8,73 & 7.53 \\
Cumulated Variance & & & & & \\
$(\%)$ & 46.86 & 65.92 & 76.18 & 84,90 & 92.43 \\
\hline
\end{tabular}

Legend: PTH = Pseudo-trunk height, BUW = Bunch weight, NHB = Number of hands per bunch, NFB = Number of fruits per bunch, FRL $=$ Fruit length, FPL $=$ Fruit pedicel length, FPD $=$ Fruit pedicel diameter, FST $=$ Fruit skin thickness, NSP $=$ Number of suckers per plant, NLF $=$ Number of living leaves at flowering stage, NLH $=$ Number of living leaves at harvest stage, $\mathrm{LBW}=$ Leaf blade width, $\mathrm{LBL}=$ Leaf blade length, $\mathrm{LMW}=$ Leaf margin width, $\mathrm{PEL}=$ Petiole length, $\mathrm{PDL}=$ Peduncle length, $\mathrm{PDD}=$ Peduncle diameter, $\mathrm{MBL}=$ Male bud length.

Table 6: Eigenvalues and proportions of variance explained by the first five factorial components of the principal component analysis.

\begin{tabular}{lllll}
\hline variables & Minimum & Maximum & Mean value & Standard deviation \\
\hline PTH $(\mathrm{m})$ & 2.04 & 3.56 & 2.66 & 0.55 \\
NSP & 3.00 & 9.00 & 5.04 & 1.75 \\
LMW $(\mathrm{cm})$ & 0.86 & 2.12 & 1.44 & 0.47 \\
LBL $(\mathrm{cm})$ & 105.40 & 199.00 & 165.444 & 31.70 \\
LBW $(\mathrm{cm})$ & 38.40 & 80.60 & 59.27 & 13.43 \\
PEL $(\mathrm{cm})$ & 27.60 & 61.40 & 47.98 & 11.79 \\
PDL $(\mathrm{cm})$ & 16.20 & 43.00 & 26.96 & 8.89 \\
PDD $(\mathrm{cm})$ & 2.32 & 5.08 & 3.58 & 0.99 \\
MBL $(\mathrm{cm})$ & 8.40 & 23.80 & 16.38 & 5.82 \\
NFB & 28.60 & 108.00 & 59.82 & 25.36 \\
FRL $(\mathrm{cm})$ & 5.30 & 27.20 & 15.23 & 7.10 \\
FPL $(\mathrm{cm})$ & 0.36 & 3.52 & 2.073 & 1.16 \\
FPD $(\mathrm{mm})$ & 0.76 & 9.20 & 2.47 & 2.60 \\
FST $(\mathrm{mm})$ & 2.00 & 3.68 & 2.82 & 0.69 \\
BUW $(\mathrm{kg})$ & 2.36 & 7.20 & 5.10 & 1.69 \\
NHB & 4.80 & 7.80 & 6.11 & 0.91 \\
NLF & 3.80 & 8.00 & 5.78 & 1.45 \\
NLH & 2.20 & 5.60 & 3.44 & 1.08 \\
\hline
\end{tabular}


Table 7: Pearson correlation coefficients between the 18 quantitative agro-morphological traits and the first five factorial components of the principal component analysis.

\begin{tabular}{|c|c|c|c|c|c|}
\hline \multirow{2}{*}{ Variables } & \multicolumn{5}{|c|}{ Factorial components } \\
\hline & F1 & F2 & F3 & F4 & F5 \\
\hline PTH (m) & 0.72 & -0.05 & -0.17 & -0.59 & 0.14 \\
\hline NSP & 0.31 & -0.70 & -0.08 & -0.43 & 0.45 \\
\hline LMW $(\mathrm{cm})$ & 0.65 & 0.37 & 0.03 & 0.55 & -0.05 \\
\hline $\operatorname{LBL}(\mathrm{cm})$ & 0.67 & 0.52 & 0.04 & -0.41 & -0.25 \\
\hline LBW (cm) & 0.93 & 0.21 & 0.04 & -0.01 & -0.02 \\
\hline PEL (cm) & 0.31 & 0.80 & -0.23 & -0.19 & 0.23 \\
\hline PDL (cm) & 0.93 & 0.03 & 0.08 & 0.22 & -0.09 \\
\hline PDD (cm) & 0.95 & 0.12 & 0.21 & 0.06 & -0.07 \\
\hline $\operatorname{MBL}(\mathbf{c m})$ & 0.90 & 0.19 & 0.01 & 0.09 & 0.35 \\
\hline NFB & 0.36 & 0.53 & 0.46 & -0.42 & 0.11 \\
\hline FRL (cm) & 0.43 & -0.68 & 0.48 & 0.17 & -0.16 \\
\hline FPL $(\mathrm{cm})$ & 0.77 & -0.60 & 0.004 & -0.03 & -0.02 \\
\hline FPD (mm) & -0.20 & 0.46 & 0.04 & 0.42 & 0.75 \\
\hline FST (mm) & 0.92 & -0.33 & 0.01 & 0.01 & 0.07 \\
\hline BUW (kg) & 0.72 & -0.51 & -0.09 & 0.20 & 0.36 \\
\hline NHB & 0.22 & 0.23 & 0.91 & 0.03 & -0.07 \\
\hline NLF & 0.70 & 0.14 & -0.52 & 0.11 & -0.27 \\
\hline NLH & 0.73 & 0.15 & -0.40 & 0.19 & -0.24 \\
\hline
\end{tabular}

Legend: PTH = Pseudo-trunk height, BUW = Bunch weight, NHB = Number of hands per bunch, NFB = Number of fruits per bunch, FRL $=$ Fruit length, FPL $=$ Fruit pedicel length, FPD $=$ Fruit pedicel diameter, FST $=$ Fruit skin thickness, NSP $=$ Number of suckers per plant, NLF $=$ Number of living leaves at flowering stage, NLH $=$ Number of living leaves at harvest stage, $\mathrm{LBW}=$ Leaf blade width, $\mathrm{LBL}=$ Leaf blade length, $\mathrm{LMW}=$ Leaf margin width, $\mathrm{PEL}=$ Petiole length, $\mathrm{PDL}=\mathrm{Peduncle}$ length, $\mathrm{PDD}=$ Peduncle diameter, $\mathrm{MBL}=$ Male bud length .

Table 8: Squared cosine of the 18 quantitative agro-morphological traits.

\begin{tabular}{lccccc}
\hline \multirow{2}{*}{ Variables } & \multicolumn{5}{c}{ Factorial components } \\
\cline { 2 - 6 } & F1 & F2 & F3 & F4 & F5 \\
\hline PTH $(\mathrm{m})$ & $\mathbf{0 . 5 1}$ & 0.00 & 0.03 & 0.35 & 0.02 \\
NSP & 0.10 & $\mathbf{0 . 4 9}$ & 0.01 & 0.19 & 0.20 \\
LMW (cm) & $\mathbf{0 . 4 2}$ & 0.14 & 0.00 & 0.30 & 0.00 \\
LBL $(\mathrm{cm})$ & $\mathbf{0 . 4 6}$ & 0.27 & 0.00 & 0.17 & 0.06 \\
LBW $(\mathrm{cm})$ & $\mathbf{0 . 8 6}$ & 0.04 & 0.00 & 0.00 & 0.00 \\
PEL $(\mathrm{cm})$ & 0.10 & $\mathbf{0 . 6 4}$ & 0.05 & 0.04 & 0.05 \\
PDL $(\mathrm{cm})$ & $\mathbf{0 . 8 6}$ & 0.00 & 0.01 & 0.05 & 0.01 \\
PDD $(\mathrm{cm})$ & $\mathbf{0 . 9 0}$ & 0.01 & 0.04 & 0.00 & 0.01 \\
MBL $(\mathbf{c m})$ & $\mathbf{0 . 8 2}$ & 0.04 & 0.00 & 0.01 & 0.12 \\
NFB & 0.13 & $\mathbf{0 . 2 8}$ & 0.21 & 0.17 & 0.01 \\
FRL $(\mathrm{cm})$ & 0.19 & $\mathbf{0 . 4 6}$ & 0.23 & 0.03 & 0.03 \\
FPL $(\mathrm{cm})$ & $\mathbf{0 . 6 0}$ & 0.36 & 0.00 & 0.00 & 0.00 \\
FPD $(\mathrm{mm})$ & 0.04 & 0.21 & 0.00 & 0.17 & $\mathbf{0 . 5 7}$ \\
FST $(\mathrm{mm})$ & $\mathbf{0 . 8 5}$ & 0.11 & 0.00 & 0.00 & 0.00 \\
BUW $(\mathrm{kg})$ & $\mathbf{0 . 5 3}$ & 0.26 & 0.01 & 0.04 & 0.13 \\
NHB & 0.05 & 0.05 & $\mathbf{0 . 8 2}$ & 0.00 & 0.01 \\
NLF & $\mathbf{0 . 4 9}$ & 0.02 & 0.27 & 0.01 & 0.07 \\
NLH & $\mathbf{0 . 5 3}$ & 0.02 & 0.16 & 0.03 & 0.06 \\
\hline
\end{tabular}

Legend: PTH = Pseudo-trunk height, BUW = Bunch weight, NHB = Number of hands per bunch, NFB = Number of fruits per bunch, FRL $=$ Fruit length, FPL $=$ Fruit pedicel length, FPD $=$ Fruit pedicel diameter, FST $=$ Fruit skin thickness, NSP $=$ Number of suckers per plant, NLF $=$ Number of living leaves at flowering stage, NLH $=$ Number of living leaves at harvest stage, $\mathrm{LBW}=$ Leaf blade width, $\mathrm{LBL}=$ Leaf blade length, $\mathrm{LMW}=$ Leaf margin width, $\mathrm{PEL}=$ Petiole length $\mathrm{PDL}=\mathrm{Peduncle}$ length, $\mathrm{PDD}=$ Peduncle diameter, $\mathrm{MBL}=$ Male bud length. 


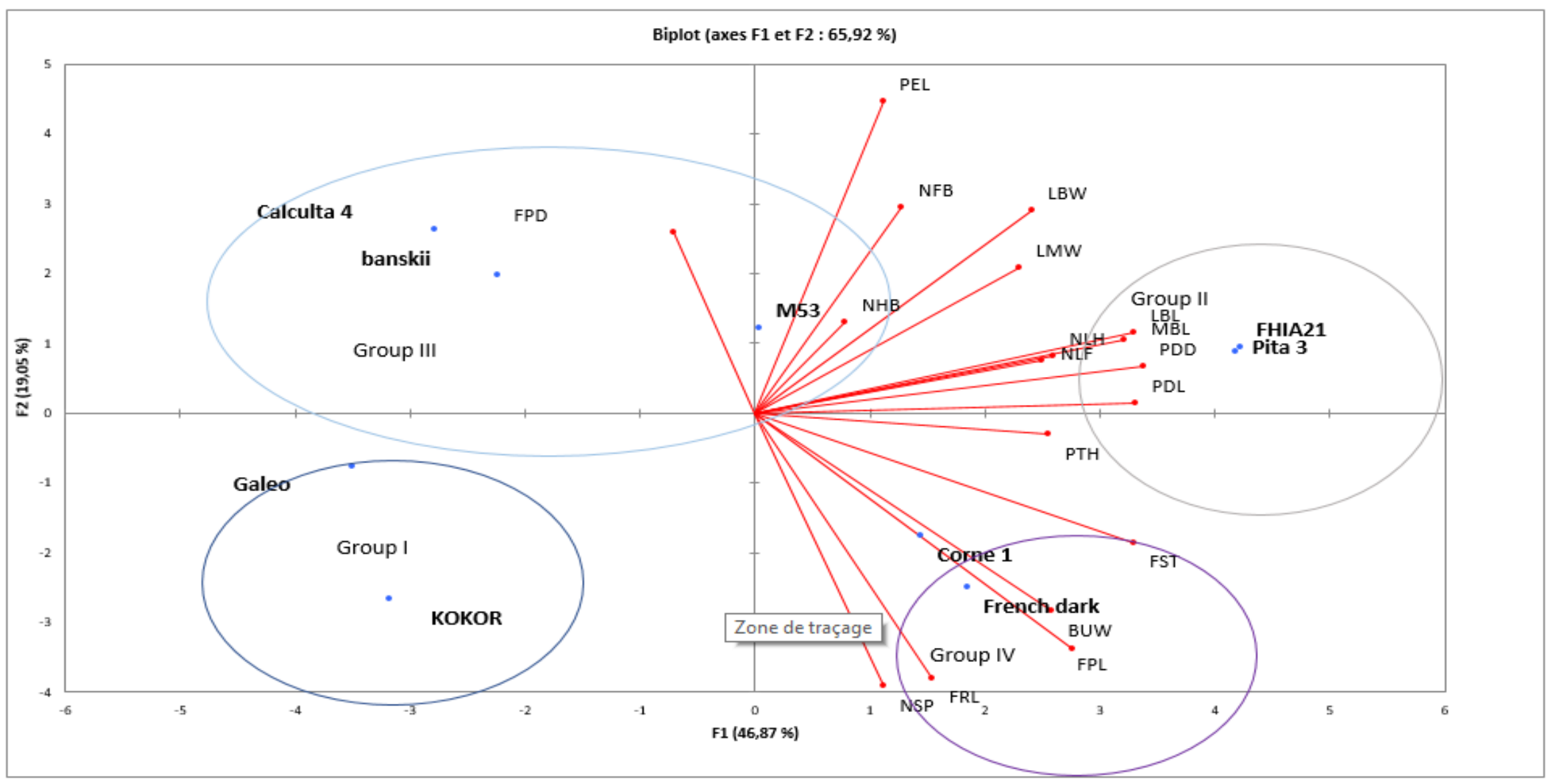

Figure 1: Projection of the plantain accessions and agro-morphological traits in the space determined by factorial components F1 and F2 of the principal component analysis. 


\section{DISCUSSION}

The absence of differences in the modalities frequencies of some quantitative variables means that, these variables do not clearly differentiate accessions. Sanni et al. (2010) and N'da et al. (2014) made similar observations respectively on rice and on maize, where many of the qualitative variables assessed did not differentiate very clearly the plant varieties cultivated. The variation of pseudo-trunk colour obtained among assessed accessions proved the heterogeneity of the accessions for this character. The study of Swennen and Vuylsteke (2001) on some plantain varieties, showed a variation in the pseudo-trunk colour from yellow, green, red to purplish red. Our findings are similar to their result. Pita 3 and FHIA 21 are improved verities introduced in Cote d'Ivoire by the CNRA for their resistance to Sigatoka, this may probably explain the absence this disease symptoms on their leaves. Tomekpe et al. (2004) reported in their studies that the hybrid M53 is resistant to black sigatoka disease. Calcuta 4 accessions has also been recognised as resistance to black sigatoka disease (Sánchez Timm et al., 2016). This may be a plausible explanation to the absence of symptom of black sigatoka on our studied accessions.

The large variations obtained between the minimum values and the maximum values of the accessions from the descriptive statistic of quantitative variables demonstrate a strong phenotypic heterogeneity and diversity between the accessions. The average pseudotrunk height of $2.66 \mathrm{~m}$ of the accessions obtained from our study is in accordance to the recommended value reported by Jones (2000). The author postulated that an ideal plantain should have a pseudo-trunk height less than 3 $\mathrm{m}$. This height of pseudo-trunk is reported to withstand climatic threats (Violent wind and so one) (Jones, 2000). The high number of suckers of French sombre accession reported in this study is a good agronomic feature for the sustainable reproduction of plantain (Pascal et al., 2007).

The four groups of plantain accessions obtained from PCA of the quantitative variables is perfect because each has very important and particular agronomic characteristics, which can be exploited differently in genetic improvement programme according to the breeding objective. For instance, the accessions of the first group (group I) are cultivars from Papua New Guinea which could be can be used to increase fruits sizes. The Group III accessions are diploids and they could be better spawners to increase the number of fruits and hands of the bunch. And the Group IV accessions are the most cultivated Ivorian local landraces with probably the characteristics of fruits with producers and consumers preference. Hence, they could be used to increase the fruits sizes, yield and fruits quality.

\section{Conclusion}

Agro-morphological characterization revealed a strong variability among the accessions studied. From these results, it appears clearly that the objective is achieved. However, knowing that morphological descriptors are influenced by environmental factors, molecular and cytogenetic characterization would be more relevant. Also, the assessment of pollen and gametophytic fertility, suitability for combination, seed production would be even more judicious. 


\section{COMPETING INTERESTS}

The authors declare that they have no competing interests.

\section{AUTHORS' CONTRIBUTIONS}

AAI monitored experiments, collected data and participated in the article writing; ANO Guided the field experiments, participated and finalized the article; TD plane the experimental protocol, guided the field experiments and participated in the article writing.

\section{ACKNOWLEDGMENTS}

Authors thank the CNRA for providing the equipment, capitals et materials, and the Genetic laboratory of Felix Houphouet-Boigny University for guiding scientifically the work.

\section{REFERENCES}

Chah JM, Ani NA, Irohibe JI, Agwu A. 2012. Creative Commons User Licence: CC BY-NC-ND. JAE， 18(2):10-20. DOI: https://doi.org/10.4314/jae.v20i2.10

Coretta C, Anda O, Ndong AN, Ndoutoumou PN, Loubana PM. 2020. Impact of arbuscular mycorrhizal fungus (Rhizophagus irregularis) on disease symptoms caused by the ascomycete fungus (Mycosphaerella fijiensis M.) in Black Sigatoka-resistant banana plantain. Int. J. Biol. Chem. Sci., 14(2): 306-316. DOI:

https://doi.org/10.4314/ijbcs.v14i2.1

Gueye PS, Labou B, Diatte M, Diarra K. 2020.

La mauvaise pratique phytosanitaire, principale source de contamination du chou au Sénégal Poor phytosanitary practice, the main source of cabbage contamination in Senegal. Int. J. Biol. Chem. Sci., 14(2): 539-554. DOI: https://doi.org/10.4314/ijbcs.v14i2.19

Jones DR. 2008. Handbook of Diseases of Banana, Abacá and Enset. Cabi Publishing: Wallingford, UK.

FAO. 2019. FAOSTAT production databases.

Food and Agriculture Organization. http://www.faostat3.fao.org.

FAO. 2016. FAOSTAT production databases.

Food and Agriculture Organization. http://www.faostat3.fao.org.

N'Da HA, Akanvou L, Akanvou R, Zoro BIA. 2014. Évaluation de la diversité agromorphologique des accessions de maïs (Zea mays 1.) collectées en Côte d'Ivoire. JAPS, 20 (3): 3144-3158

Nwauzoma AB, Uma S, Saraswathi MS, Mustaffa M. 2011. Developing markers for Sigatoka leaf spot disease (mycosphaerella musicola leach) resistance in banana (Musa spp.). $A B J$, 10(33): 6213-6219. DOI: https://doi.org/10.5897/AJB11.485

Ocab. 2012. Organisation Centrale des producteurs-exportateurs de l'Ananas et de la Banane Document interne des statistiques agricoles 7-9

Oselebe HO, Tenkouano A, Pillay M. 2006. Ploidy variation of Musa hybrids from crosses. ABJ, 5(11): 1048-1053. DOI: https://doi.org/10.5897/AJB05.386

Noupadja P, Tomekpe K, Youmbi E. 2007. Évaluation d'hybrides tétraploïdes de bananiers plantains (Musa spp.) résistants à la maladie des raies noires créés au Cameroun. Published online by Cambridge University Press, 62(2): 7788

DOI : https://doi.org/10.1051/fruits:2007 001.

Sanni KA, Fawole I, Ogunbayo A, Tia D, Somado EA, Futakuchi K, Sié M, 
Nwilene FE, Guei RG. 2010. Analyse multivariée de la diversité du matériel génétique des variétés locales de riz, CSSA, 52 (2): 494-50.

Sánchez TE, Hidalgo PL, Pacheco CR, Chávez NT, Navarrete VO, Santos OE. 2016. Identification of differentially-expressed genes in response to Mycosphaerella fijiensis in the resistant Musa accession "Calcutta-4" using suppression subtractive hybridization. PLOS ONE, 11(8). DOI: https://doi.org/10.1371/journal.pone.016 0083

Shirani S, Mahdavi F, Maziah M. 2009.
Morphological abnormality among regenerated shoots of banana and plantain (Musa spp.) after in vitro multiplication with TDZ and BAP from excised shoottips. $A B J, \mathbf{8}(21)$ : 5755-5761.

Swennen R, Vuylsteke D. 2001. Breeding black Sigatoka resistant plantains with a wild banana. Trop. Agric, 70: 74-78.

Tomekpe K, Jenny C, Escalant JV. 2004. Revue des stratégies d'amélioration conventionnelle de Musa. Info Musa, revue internationale sur le Bananiers et Plantains 2-5. 